\title{
Morphological and chemical variability of common oregano (Origanum vulgare L. subsp. vulgare) occurring in eastern Poland
}

\author{
OLGA KOSAKOWSKA*, WERONIKA CZUPA
}

Laboratory of New Herbal Products

Department of Vegetable and Medicinal Plants

Warsaw University of Life Sciences - SGGW

Nowoursynowska 166

02-787 Warsaw, Poland

*corresponding author: phone: +48 22 5932247, fax +48 22 5932232, e-mail: olga_kosakowska@sggw.pl

\section{Summary}

Introduction: Common oregano is an important medicinal and aromatic plant, characterized by a high morphological and chemical variability.

Objective: The aim of the work was to determine the diversity of 14 common oregano populations introduced into ex situ conditions, in respect of morphological and developmental traits as well as content and composition of essential oil in herb.

Methods: Observations and harvest of raw material were performed in the second year of plant vegetation. Morphological and developmental characters were estimated. Total content of essential oil was determined according to European Pharmacopoeia 8th. The composition of essential oil was carried out by gas chromatography.

Results: Populations differed in respect of examined traits, i.a.: plant's height from 52.13 to $88.66 \mathrm{~cm}$, number of stems per plant from 45.6 to 123.3, number of internodes per stem from 4.6 to 9.2. Fresh mass of herb was at a level of $249.0-896.6 \mathrm{~g}$ per plant. Total content of essential oil ranged from 0.35 to $0.87 \%$. Sabinene, 1,8 -cineole, linalool, $p$-cymene, $\beta$-caryophyllene and caryophyllene oxide were the dominant compounds in essential oil.

Conclusions: Number of stems and fresh mass of herb differentiated examined populations at the highest degree. Most of populations were classified as a sabinyl chemotype rich in sesquiterpenes.

Key words: common oregano, populations, essential oil, chemotypes, variability 


\section{INTRODUCTION}

The genus Origanum (Lamiaceae family) consist of 49 taxa belonging to 10 sections. Several species of this genus, including Origanum vulgare L., are rich in essential oil and commonly known as 'oregano'. $O$. vulgare is a perennial, widely distributed all over Euroasia and North Africa. Its herb is considered as one of the most traded and consumed spice [1]. It also reveals a wide range of pharmacological activities, especially antimicrobial [2-5]. Given its significant economic importance and a specific biological character, $O$. vulgare has been included into the List of Priority Species in Europe [6].

The species is extremely variable, both in its morphological traits and chemical composition [1]. According to latest taxonomy, six subspecies have been distinguished on the bases of morphological features, i.e.: O. vulgare L. subsp. glandulosum (Desfontaines) Ietswaart, O. vulgare L. subsp. hirtum (Link) Ietswaart, O. vulgare L. subsp. gracile (Koch) Ietswaart, O. vulgare L. subsp. virens (Hoffmannsegg et Link) Ietswaart, O. vulgare L. subsp. vulgare L. and O. vulgare L. subsp. viride (Boissier) Hayek [7]. It is known that subspecies differ significantly in respect of total content and composition of essential oil. This variability is strongly related to its geographical origin. It is considered that southernmost subspecies (subsp. glandulosum, subsp. hirtum and subsp. gracile) are rich in essential oil (more than $2 \%$ ), while those from northern parts (subsp. virens, subsp. vulgare, subsp. viride) are medium or poor sources of volatiles $[1,8]$. In general, subspecies characterized by high amount of essential oil usually accumulate carvacrol and/or thymol and their precursors ( $\gamma$-terpinene and $p$-cymene), while those with low amount of essential oil are rich in other monoterpenes, e.g.: linalool, sabinene, borneol and its derivatives, often accompanied by high amounts of various sesquiterpenes [9]. It is worth noting that each $O$. vulgare subspecies create several different chemotypes defined on the basis of main compound in essential oil. This phenomenon is widely described in current literature [8-16]. However, despite of commonly accepted taxonomy, some authors treat $O$. vulgare as a collective species and do not distinguish particular subspecies [17-19]. Such data, based only on essential oil composition excluding morphological characters, can confuse understanding the complex problem of oregano variability.

O. vulgare subsp. vulgare (common oregano) is spread on the area of Central and Northern Europe and is the only representative of O. vulgare in Poland $[16,20]$. It is a woody perennial, up to $100 \mathrm{~cm}$ tall. Its leaves are usually ovate and weakly pubescent with dentate margin and acute or rounded apex. Colour of petals range from white to purple. The plants are blooming from May to October [7]. They occur naturally in various type of habitats, e.g.: edges of forests, clearings, semi-dry meadows and wastelands [20]. Common oregano is important medicinal and aromatic plant. In herb there is up to $1.8 \%$ of essential oil containing predominantly sabinene, $p$-cymene, $\beta$-caryophyllene, linalool etc. [21-27]. According to Chalcate and Pasquier, O. vulgare subsp. vulgare is able to create nine different chemotypes [28]. This raw material is rich also in phenolic compounds, mainly phenolic acids and flavonoids. Among phenolic acids, the rosmarinic acid is present in the highest amount, followed by caffeic, vanillic, $o$-coumaric and protocatechuic acids. Flavonoids are represented here mainly by apigenine, luteoline and its derivatives [16, 26, 29]. Common oregano herb reveals various pharmacological activities, i.e. antibacterial and antifungal, diuretic, choleretic, expectorant and antioxidant $[2,3,30]$. It is used in gastrointestinal and upper respiratory tract disorders treatment, especially in veterinary. Due to a pleasant aroma, this raw material can be used as spice, as well [30].

In Poland, herb of $O$. vulgare subsp. vulgare is collected both from natural sites and cultivation. According to Lukas et al. [16], in the case of this subspecies, collection from the wild not only results in heterogeneous raw material but also can lead to genetic erosion. Data concerning wild growing common oregano populations in Europe show the impressive variability of this taxon [16, 21-23, 25]. However, such research investigated on the area of Poland are rather scarce $[26,27,31]$.

The aim of the present study was to determine the differences between selected common oregano populations introduced into ex situ conditions, in respect of developmental and morphological traits as well as content and composition of essential oil in herb.

\section{MATERIAL AND METHODS}

\section{Plant material}

Objects of the study were 14 common oregano populations (accessions) originating from eastern 
Poland (Podlaskie, Lubelskie and Podkarpackie voivodeships), introduced to ex situ conditions (tab. 1). In August 2011, at each natural site the vegetative cuttings were collected from 25 randomly chosen plants and used for establishing a field experiment, performed at the Experimental Field of Department of Vegetable and Medicinal Plants, WULS-SGGW, according to pattern described by Bączek et al. [32]. The morphological observations and harvest of raw material was done in the second year of plant vegetation (2013), at the beginning of plants blooming (June). Collected herb was dried at $35^{\circ} \mathrm{C}$ and subjected to chemical analysis.

Populations' seeds are kept in the National Centre for Plant Genetic Resources (Polish GeneBank), while alive plants grow in the field collection of medicinal and aromatic plants of Department of Vegetable and Medicinal Plants.

\section{Morphological observations}

Morphological and developmental characters of investigated populations were estimated according to the List of Descriptors for O. vulgare L. elaborated by Medicinal and Aromatic Plants Working Group of European Cooperative Programme for Plant Genetic Recourses [33]. Observations were carried out directly before harvest of raw material (June, 2013) and concerned important features differentiating species, as following: plant growth habit, plant height $(\mathrm{cm})$, number of stems per plant, branching density, stem color, pubescence and degree of lignification, number of internodes per stem, foliage density, leaf length and width, shape of blade, leaf margin, shape of apex, color of petals. The beginning of flowering was evaluated (when $50 \%$ of inflorescence had flower buds). Fresh mass of herb $\left(\mathrm{g} \times\right.$ plant $\left.^{-1}\right)$ was also determined. At each population, the observations were conducted on ten plants.

\section{Chemical analysis}

Total content of essential oil was determined according to European Pharmacopoeia 8th [34]. The composition of essential oil was carried out by gas chromatography. All measurements were performed in triplicate.

The chromatographic analysis was performed using a Hewlett Packard 6890 gas chromatograph equipped with a flame ionization detector (FID) and capillary, polar column Quadrex $007 \mathrm{CW}$ ( $25 \mathrm{~m}$ $\times 0.25 \mathrm{~mm} \times 0.25 \mu \mathrm{m}$ film thickness). The analysis was carried out using the following temperature programme: oven temperature isotherm at $60^{\circ} \mathrm{C}$ for $2 \mathrm{~min}$., then rising from $60^{\circ} \mathrm{C}$ to $220^{\circ} \mathrm{C}$ at a rate of $4^{\circ} \mathrm{C}$ per min. and held isothermal at $220^{\circ} \mathrm{C}$ for $5 \mathrm{~min}$. Injector and detector temperatures were, respectively, at $220^{\circ} \mathrm{C}$ and $260^{\circ} \mathrm{C}$. The carrier gas $(\mathrm{He})$ flow was $1.1 \mathrm{ml} \times \mathrm{min}^{-1}$. The split ratio was $1: 70$. Manually injection of $0.5 \mu \mathrm{l}$ essential oil was applied. Component identification was confirmed by pure authentic samples retention times and comparison

Table 1.

Geographical localization of natural sites of investigated populations

\begin{tabular}{|c|c|c|c|c|c|}
\hline \multicolumn{2}{|c|}{ Population no./site } & \multirow{2}{*}{$\begin{array}{l}\text { Accession no } \\
401284\end{array}$} & \multicolumn{2}{|c|}{ Coordinates } & \multirow{2}{*}{$\begin{array}{c}\text { Province/Voivodeship } \\
\text { Podlaskie }\end{array}$} \\
\hline 1 & Drohiczyn 1 & & N $52^{\circ} 24^{\prime}$ & E $022^{\circ} 38^{\prime}$ & \\
\hline 2 & Drohiczyn 2 & 401285 & $\mathrm{~N} 52^{\circ} 23^{\prime}$ & E $022^{\circ} 39^{\prime}$ & \\
\hline 3 & Radecznica & 401286 & N $50^{\circ} 44^{\prime}$ & E $022^{\circ} 48^{\prime}$ & Lubelskie \\
\hline 4 & Czarnystok & 401287 & N 50³8' & E $022^{\circ} 49^{\prime}$ & \\
\hline 5 & Zwierzyniec & 401288 & N $50^{\circ} 37^{\prime}$ & E $022^{\circ} 50^{\prime}$ & \\
\hline 6 & Lipowiec & 401289 & N $50^{\circ} 37^{\prime}$ & E $022^{\circ} 51^{\prime}$ & \\
\hline 7 & Karlików & 401293 & $\mathrm{~N} 49^{\circ} 26^{\prime}$ & E $022^{\circ} 05^{\prime}$ & Podkarpackie \\
\hline 8 & Bukowsko & 401294 & $\mathrm{~N} 49^{\circ} 27^{\prime}$ & $\mathrm{E} 022^{\circ} 03^{\prime}$ & \\
\hline 9 & Eukowe & 401295 & $\mathrm{~N} 49^{\circ} 26^{\prime}$ & E $022^{\circ} 15^{\prime}$ & \\
\hline 10 & Monasterzec & 401296 & $\mathrm{~N} 49^{\circ} 31^{\prime}$ & E $022^{\circ} 19^{\prime}$ & \\
\hline 11 & Jawornik & 401297 & $\mathrm{~N} 49^{\circ} 21^{\prime}$ & E $022^{\circ} 05^{\prime}$ & \\
\hline 12 & Gruszka & 401298 & $\mathrm{~N} 49^{\circ} 27^{\prime}$ & E $022^{\circ} 16^{\prime}$ & \\
\hline 13 & Łupków & 401299 & $\mathrm{~N} 49^{\circ} 14^{\prime}$ & E $022^{\circ} 06^{\prime}$ & \\
\hline 14 & Babice & 401301 & $\mathrm{~N} 49^{\circ} 48^{\prime}$ & E $022^{\circ} 28^{\prime}$ & \\
\hline
\end{tabular}


of linear retention indices (RI) relative to the series of $n$-hydrocarbons (C7-C30), under the same operating conditions. The percentage content of determined essential oils compounds was computed by the normalization method from the GC peak areas, without the use of correction factors.

\section{Statistical analysis}

Data were subjected to statistical analysis using Statistica ${ }^{\oplus}$ software. The coefficient of variation $(C V)$ was determined.

Ethical approval: The conducted research is not related to either human or animal use.

\section{RESULTS AND DISSCUSION}

Examined common oregano populations differ both in morphological and chemical characters. It was observed that most of them were characterized by erect type of growth habit, with one exception: population no 12 represented semi-erect type (tab. 2). Plant's height varied from 52.13 to $88.66 \mathrm{~cm}$, while number of stems per plant from 45.6 to 123.3. Number of internodes per stem ranged from 4.6 to 9.2 . The branching density was described as intermediate (6 populations), sparce (5 populations) or dense (3 populations) (tab. 2 and 3 ). Results by Sivicka et al. [35] show similar range of plant's height $(50.1-85.0 \mathrm{~cm})$, however, most accessions were characterized there by semi-erect type

Table 2.

Morphological and developmental traits of investigated populations

\begin{tabular}{|c|c|c|c|c|c|c|c|c|c|c|}
\hline Population no./site & $\begin{array}{l}\text { Plant } \\
\text { growth } \\
\text { habit }\end{array}$ & $\begin{array}{l}\text { Branching } \\
\text { density }\end{array}$ & $\begin{array}{l}\text { Color of } \\
\text { stems }\end{array}$ & $\begin{array}{l}\text { Stem } \\
\text { pubescence }\end{array}$ & $\begin{array}{l}\text { Degree } \\
\text { of stem } \\
\text { lignification }\end{array}$ & $\begin{array}{l}\text { Foliage } \\
\text { density }\end{array}$ & $\begin{array}{l}\text { Shape of } \\
\text { blade }\end{array}$ & Leaf margin & $\begin{array}{l}\text { Color of } \\
\text { petals }\end{array}$ & $\begin{array}{l}\text { Beginning of } \\
\text { flowering* }\end{array}$ \\
\hline Drohiczyn 1 & erect & intermediate & green & $\begin{array}{l}\text { slighty } \\
\text { hairy }\end{array}$ & $\begin{array}{l}\text { slighty } \\
\text { ligneous }\end{array}$ & medium & oblong & entire & pink & late \\
\hline Drohiczyn 2 & erect & dense & $\begin{array}{l}\text { dark red } \\
\text { and green }\end{array}$ & $\begin{array}{l}\text { slighty } \\
\text { hairy }\end{array}$ & ligneous & medium & ovate & denticulate & pink & late \\
\hline Radecznica & erect & intermediate & green & $\begin{array}{l}\text { slighty } \\
\text { hairy }\end{array}$ & $\begin{array}{l}\text { slighty } \\
\text { ligneous }\end{array}$ & medium & ovate & denticulate & pink & average \\
\hline Czarnystok & erect & sparce & green & $\begin{array}{l}\text { slighty } \\
\text { hairy }\end{array}$ & $\begin{array}{l}\text { slighty } \\
\text { ligneous }\end{array}$ & medium & oblong & dentate & pink & average \\
\hline Zwierzyniec & erect & dense & green & $\begin{array}{l}\text { slighty } \\
\text { hairy }\end{array}$ & $\begin{array}{l}\text { slighty } \\
\text { ligneous }\end{array}$ & medium & ovate & denticulate & pink & early \\
\hline Lipowiec & erect & sparce & green & $\begin{array}{l}\text { slighty } \\
\text { hairy }\end{array}$ & $\begin{array}{l}\text { slighty } \\
\text { ligneous }\end{array}$ & medium & rhomboid & denticulate & pink & average \\
\hline Karlików & erect & intermediate & $\begin{array}{l}\text { dark red } \\
\text { and green }\end{array}$ & hairy & $\begin{array}{l}\text { slighty } \\
\text { ligneous }\end{array}$ & medium & oblong & denticulate & pink & average \\
\hline Bukowsko & erect & sparce & green & $\begin{array}{l}\text { slighty } \\
\text { hairy }\end{array}$ & ligneous & dense & rhomboid & dentate & white & average \\
\hline 9 Łukowe & erect & intermediate & $\begin{array}{l}\text { dark red } \\
\text { and green }\end{array}$ & $\begin{array}{l}\text { slighty } \\
\text { hairy }\end{array}$ & ligneous & medium & rhomboid & denticulate & $\begin{array}{l}\text { pale } \\
\text { lilac }\end{array}$ & early \\
\hline 10 Monasterzec & erect & intermediate & $\begin{array}{l}\text { dark red } \\
\text { and green }\end{array}$ & $\begin{array}{l}\text { slighty } \\
\text { hairy }\end{array}$ & $\begin{array}{l}\text { slighty } \\
\text { ligneous }\end{array}$ & medium & oblong & dentate & $\begin{array}{l}\text { pale } \\
\text { lilac }\end{array}$ & early \\
\hline 11 Jawornik & erect & sparce & green & $\begin{array}{l}\text { slighty } \\
\text { hairy }\end{array}$ & ligneous & medium & oblong & entire & $\begin{array}{l}\text { pale } \\
\text { lilac }\end{array}$ & early \\
\hline 12 Gruszka & $\begin{array}{l}\text { semi- } \\
\text { erect }\end{array}$ & intermediate & $\begin{array}{l}\text { dark red } \\
\text { and green }\end{array}$ & $\begin{array}{l}\text { slighty } \\
\text { hairy }\end{array}$ & $\begin{array}{l}\text { slighty } \\
\text { ligneous }\end{array}$ & dense & rhomboid & denticulate & pink & early \\
\hline 13 Łupków & erect & sparce & green & hairy & $\begin{array}{l}\text { slighty } \\
\text { ligneous }\end{array}$ & dense & ovate & denticulate & pink & early \\
\hline 14 Babice & erect & dense & green & $\begin{array}{l}\text { slighty } \\
\text { hairy }\end{array}$ & ligneous & medium & rhomboid & dentate & pink & average \\
\hline
\end{tabular}

*early - the end of June, average - first decade of July, late - second decade of July 
of growth habit and sparce branching density. The color of stems of evaluated populations was green or dark red and green. Regarding stem pubescence, majority of populations had slightly hairy stems and only two were distinguished by hairy ones. Five of investigated populations were characterized by ligneous stems, while the others - slightly ligneous. Studied populations varied in terms of leaves and flowers characters, as well. The foliage density was medium for most populations, however the shape of blade, leaf margin and shape of apex were strongly differentiated. It is worth noting that almost all populations originated from Bieszczady (Podkarpackie Voivodeship) were characterized by rounded shape of apex, while the others - acute one. The length and width of leaves ranged from 20 to $40 \mathrm{~mm}$ and from 10 to $20 \mathrm{~mm}$, respectively. Population No. 11 was distinguished by the highest area of leaf blade. In the most cases flower's petals were pink, three populations had pale lilac color and there was one population with white flower's petals (tab. 2 and 3). In observations of Sivicka et al. [35] $77 \%$ of populations was characterized by pink flower's petals, as well. In present study, populations differed also as to the earliness of blooming: these from Podlaskie Voivodeship started flowering later than the others (tab. 2). Listed traits, especially type of growth, the degree of lignification, the branching and foliar density as well as number of stems can be important from practical point of view since they impact on the yield of herb and enable its mechanical harvest. In present work, the fresh mass of herb ranged from 249.0 to $896.6 \mathrm{~g}$ per plant. This character differentiated examined populations at the highest degree $(C V=0.38)$ and in a few cases was related to high number of stems per plant (e.g. populations no 3 and 7) (tab. 3). According to Osińska [31], fresh mass of common oregano herb varied from 784 to $1580 \mathrm{~g}$ per plant and depended on the population. However, Sivicka et al. [36] show much lower values: the average fresh mass of two-year-old plants was at the level of $127.5 \mathrm{~g}$ per plant. It can be suspected that such various results may be related both to genetic factors and environmental conditions, since research of Sivicka et al. [36] was carried out on the area of Latvia.

It was observed that the total content of essential oil in herb of examined populations varied from 0.35 to $0.87 \%$ (tab. 4). In general, such results corresponds to those obtained by other authors and confirm the thesis that O. vulgare subsp. vulgare belongs to the essential oil-poor group of oregano subspecies [1]. For instance, Lukas et

Table 3.

Morphological and developmental traits of investigated populations, continued

\begin{tabular}{|c|c|c|c|c|c|c|c|}
\hline \multicolumn{2}{|c|}{ Population o./site } & \multirow{2}{*}{$\begin{array}{l}\begin{array}{l}\text { Plant height } \\
{[\mathrm{cm}]}\end{array} \\
83.06\end{array}$} & \multirow{2}{*}{$\begin{array}{l}\begin{array}{l}\text { Number of } \\
\text { stems per plant }\end{array} \\
65.7\end{array}$} & \multirow{2}{*}{$\begin{array}{l}\text { Number of } \\
\text { internodes per } \\
\text { stems } \\
8.1\end{array}$} & \multirow{2}{*}{$\begin{array}{l}\begin{array}{l}\text { Length of leaf } \\
{[\mathrm{mm}]}\end{array} \\
30\end{array}$} & \multirow{2}{*}{$\begin{array}{l}\text { Width of leaf } \\
{[\mathrm{mm}]} \\
15\end{array}$} & \multirow{2}{*}{$\begin{array}{l}\text { Fresh mass of herb } \\
{\left[\mathrm{g} \times \text { plant }^{-1}\right]} \\
885.0\end{array}$} \\
\hline 1 & Drohiczyn 1 & & & & & & \\
\hline 2 & Drohiczyn 2 & 63.53 & 80.3 & 7.8 & 25 & 15 & 493.3 \\
\hline 3 & Radecznica & 88.66 & 112.0 & 8.3 & 25 & 15 & 896.6 \\
\hline 4 & Czarnystok & 67.87 & 65.3 & 7.9 & 20 & 10 & 249.0 \\
\hline 5 & Zwierzyniec & 56.13 & 50.0 & 4.6 & 30 & 17 & 433.0 \\
\hline 6 & Lipowiec & 78.67 & 67.7 & 7.5 & 30 & 20 & 566.0 \\
\hline 7 & Karlików & 67.73 & 123.3 & 7.2 & 35 & 15 & 870.0 \\
\hline 8 & Bukowsko & 52.13 & 95.0 & 7.9 & 30 & 18 & 766.7 \\
\hline 9 & Łukowe & 80.27 & 91.0 & 6.1 & 30 & 15 & 618.3 \\
\hline 10 & Monasterzec & 66.80 & 95.0 & 7.0 & 35 & 15 & 576.7 \\
\hline 11 & Jawornik & 66.20 & 45.6 & 5.8 & 40 & 20 & 263.0 \\
\hline 12 & Gruszka & 55.07 & 55.7 & 7.5 & 25 & 18 & 423.0 \\
\hline 13 & Łupków & 62.40 & 81.6 & 9.2 & 30 & 20 & 435.0 \\
\hline 14 & Babice & 76.33 & 65.0 & 6.9 & 30 & 18 & 483.3 \\
\hline & Mean & 67.82 & 80.57 & 7.12 & 16.73 & 16.73 & 594.46 \\
\hline & $S D$ & 11.09 & 23.36 & 1.22 & 2.81 & 2.81 & 223.28 \\
\hline & $C V$ & 0.16 & 0.29 & 0.17 & 0.17 & 0.17 & 0.38 \\
\hline
\end{tabular}


Table 4.

The total content (\%) and gas chromatographic composition (\% peak area) of essential oil samples

\begin{tabular}{|c|c|c|c|c|c|c|c|c|c|c|c|c|c|c|c|}
\hline & \multirow[b]{2}{*}{ RI } & \multicolumn{3}{|c|}{ sabinyl type } & \multicolumn{3}{|c|}{$\begin{array}{l}\text { mixed sabinyl } \\
+1,8 \text {-cineol }\end{array}$} & \multicolumn{2}{|c|}{$\begin{array}{c}\text { mixed } \\
\text { sabinyl + } \\
\text { acyclic }\end{array}$} & \multirow{2}{*}{$\begin{array}{c}\text { mixed } \\
\text { sabinyl } \\
+ \text { cymyl } \\
4\end{array}$} & \multirow{2}{*}{$\begin{array}{c}\begin{array}{c}\text { acyclic } \\
\text { type }\end{array} \\
6\end{array}$} & \multicolumn{3}{|c|}{$\begin{array}{l}\text { mixed acyclic + } \\
\text { sesquiterpenes }\end{array}$} & \multirow{2}{*}{$\begin{array}{c}\begin{array}{c}\text { mixed } \\
\text { cymyl } \\
+ \text { sesquiter- } \\
\text { penes }\end{array} \\
2 \\
\end{array}$} \\
\hline & & 1 & 3 & 13 & 11 & 5 & 9 & 10 & 14 & & & 7 & 8 & 12 & \\
\hline Total content & & 0.83 & 0.37 & 0.80 & 0.87 & 0.63 & 0.83 & 0.35 & 0.57 & 0.63 & 0.53 & 0.50 & 0.80 & 0.53 & 0.43 \\
\hline$\alpha$-Pinene & 1028 & 1.22 & 0.91 & 1.70 & 2.15 & 0.80 & 0.80 & 1.25 & 1.57 & 0.68 & 1.96 & 1.25 & 5.56 & 3.07 & 1.38 \\
\hline$\beta$-Pinene & 1113 & 0.46 & 1.12 & 2.17 & 2.16 & 1.12 & 1,4 & 1.60 & 1.83 & 0.56 & 1.83 & 1.86 & 0.82 & 0.98 & 1.35 \\
\hline Sabinene & 1125 & 25.37 & 25.91 & 14.46 & 19.90 & 17.13 & 12.11 & 14.96 & 15.41 & 21.58 & 6.47 & 8.09 & 1.94 & 7.41 & 6.22 \\
\hline$\beta$-Myrcene & 1167 & 1.29 & 1.35 & 4.46 & 2.44 & 1.42 & 1.27 & 1.42 & 1.35 & 1.51 & 0.38 & 1.04 & 1.02 & 1.74 & 0.64 \\
\hline$\alpha$-Terpinene & 1181 & 0.40 & 0.3 & 1.45 & 0.47 & 0.92 & 0.60 & 0.92 & 0.00 & 1.67 & 0.00 & 0.15 & 0.40 & 1.57 & 0.14 \\
\hline 1,8-Cineole & 1205 & 0.85 & 2.22 & 1.45 & 11.94 & 10.03 & 14.66 & 2.33 & 8.34 & 4.48 & 8.87 & 7.91 & 0.19 & 0.44 & 1.57 \\
\hline Limonene & 1209 & 0.70 & 0.94 & 0.37 & 2.08 & 1.44 & 1.47 & 1.00 & 1.87 & 1.15 & 1.12 & 1.22 & 0.23 & 0.74 & 0.70 \\
\hline$\gamma$-Terpinene & 1247 & 3.25 & 2.50 & 6.06 & 3.65 & 5.58 & 1.76 & 8.25 & 1.48 & 6.45 & 0.15 & 1.37 & 5.74 & 6.19 & 1.60 \\
\hline p-Cymene & 1273 & 1.68 & 2.05 & 7.38 & 2.28 & 4.39 & 1.48 & 2.89 & 5.11 & 10.98 & 8.55 & 8.45 & 5.90 & 4.54 & 12.71 \\
\hline$\alpha$-Terpinolen & 1279 & 0.21 & 0.18 & 0.21 & 0.26 & 0.05 & 0.22 & 0.51 & 0.00 & 0.59 & 0.1 & 0.17 & 0.43 & 0.90 & 0.15 \\
\hline Menthon & 1458 & 0.36 & 0.27 & 2.29 & 0.67 & 2.01 & 1.49 & 1.55 & 1.98 & 0.54 & 0.67 & 4.10 & 4.66 & 2.55 & 3.65 \\
\hline Citronellal & 1481 & 0.15 & 0.22 & 0.18 & 0.00 & 0.15 & 0.17 & 0.26 & 0.29 & 0.16 & 0.24 & 0.26 & 0.22 & 0.19 & 0.26 \\
\hline Camphor & 1508 & 0.41 & 0.13 & 0.41 & 00.9 & 0.03 & 0.46 & 0.37 & 0.26 & 0.23 & 0.48 & 0.44 & 0.15 & 0.51 & 0.50 \\
\hline Linalool & 1540 & 2.72 & 3.35 & 3.31 & 5.95 & 4.03 & 1.10 & 10.44 & 14.06 & 4.85 & 32.12 & 15.01 & 24.19 & 15.97 & 4.10 \\
\hline$\beta$-Caryophyllene & 1593 & 11.45 & 14.80 & 10.75 & 9.70 & 9.79 & 18.18 & 11.78 & 10.09 & 8.33 & 3.54 & 17.76 & 19.56 & 20.12 & 21.28 \\
\hline Menthol & 1633 & 0.05 & 0.37 & 1.46 & 0.42 & 0.11 & 0.49 & 0.56 & 0.64 & 0.15 & 0.28 & 0.64 & 0.09 & 0.22 & 0.71 \\
\hline$\alpha$-Humulene & 1657 & 2.45 & 0.65 & 3.26 & 1.31 & 1.24 & 1.76 & 1.60 & 0.95 & 1.23 & 0.16 & 0.84 & 1.36 & 0.18 & 0.94 \\
\hline$\alpha$-Terpineol & 1681 & 0.78 & 1.68 & 1.25 & 3.52 & 1.72 & 4.59 & 1.73 & 3.22 & 0.72 & 3.26 & 3.80 & 1.13 & 1.24 & 1.86 \\
\hline Germacrene D & 1705 & 14.15 & 11.19 & 11.76 & 8.41 & 2.87 & 9.57 & 5.14 & 0.58 & 7.15 & 0.16 & 1.49 & 5.93 & 4.72 & 1.89 \\
\hline Geranial & 1722 & 1.24 & 1.67 & 0.28 & 1.32 & 0.11 & 0.46 & 0.83 & 1.62 & 0.13 & 1.46 & 0.09 & 0.37 & 1.41 & 0.85 \\
\hline Geranyl acetate & 1758 & 3.13 & 4.35 & 1.48 & 2.07 & 0.36 & 1.75 & 1.44 & 0.00 & 1.43 & 0.31 & 0.16 & 1.05 & 0.9 & 0.73 \\
\hline $\begin{array}{l}\text { Caryophyllene } \\
\text { oxide }\end{array}$ & 1955 & 3.03 & 2.41 & 1.28 & 0.95 & 10.49 & 2.11 & 2.68 & 3.37 & 3.69 & 9.97 & 3.88 & 2.36 & 2.48 & 8.96 \\
\hline Nerolidol & 2023 & 0.30 & 0.78 & 1.05 & 1.15 & 0.98 & 2.13 & 0.85 & 0.45 & 0.54 & 0.07 & 0.62 & 0.85 & 0.51 & 0.77 \\
\hline Thymol & 2163 & 2.05 & 1.13 & 1.68 & 1.12 & 0.50 & 0.85 & 1.96 & 2.01 & 0.63 & 1.36 & 0.78 & 1.19 & 1.45 & 1.02 \\
\hline Carvacrol & 2214 & 0.53 & 1.78 & 1.68 & 1.94 & 0.11 & 2.02 & 1.32 & 2.21 & 0.63 & 0.73 & 1.46 & 1.6 & 0.79 & 1.85 \\
\hline
\end{tabular}


al. [16] provided values from 0.1 to $1.8 \%$, while Osińska [31] indicated content from $0.3-1.3 \%$. In the present study, 25 compounds were identified in essential oil, with a domination of sabinene, 1,8-cineole, linalool, $p$-cymene, germacrene $\mathrm{D}$, $\beta$-caryophyllene and caryophyllene oxide (tab. 4). The high content of these substances in O. vulgare ssp. vulgare essential oil was reported earlier by other authors. According to the dominant compounds, a lot of chemotypes were distinguished, e.g $p$-cymene $+\beta$-caryophyllene, germacrene $\mathrm{D}+$ $\beta$-caryophyllene, sabinene, cis-sabinene hydrate, terpinen 4-ol, thymol ect. [16, 21-23, 26-28]. Although the numerous research concerning a high chemical polymorphism of common oregano were presented, many data are not clear and often not comparable with others. Some authors show chemical analysis of plant samples without any or just superficial morphological observations. It could be misleading, especially when investigations are carried out on the areas where O. vulgare subsp. vulgare coexist with other oregano subspecies $[10,15$, $17-19,24]$. It seems that results shown recently by Lukas et al. $[8,16]$ may help clarify this problem. Authors claims that each $O$. vulgare subspecies can be associated with its main chemotype, what could visibly support Ietswaart's taxonomy. However, the selection of chemotypes should be related not to particular dominants but rather to the group of compounds synthesized on special metabolic pathway. In general, plants accumulating phenolic monoterpenes (thymol and carvacrol) and its biosynthetic precursors ( $p$-cymen and $\gamma$-terpinen) belong to chemotype associated with 'cymyl' pathway, typical for essential oil-rich $O$. vulgare subspecies. In turn, plants with medium or poor oil content are characterized by less active 'cymyl' pathway in favor of the bicyclic 'sabinyl' compounds (sabinene, cis/trans sabinene hydrate and its acetates) or acyclic ones (i.a. linalool, linalyl acetate, $\beta$-myrcen, $\beta$-ocimene), accompanied by high amounts of sesquiterpenes (i.a. $\beta$-caryophyllene, caryophyllene oxide, germacrene D). It seems that the activity of mentioned biosynthetic pathways is strongly regulated by environmental conditions. In plants originating from Mediterranean climate, geranyl pyrophosphate (GPP) is usually converted by 'cymyl' or 'acyclic' pathways exhibited in domination of carvacrol in O.vulgare subsp. hirtum or linalool in O. vulgare subsp. virens, respectively. In case of $O$. vulgare subsp. vulgare, a plant typical for continental climate, GPP is transformed by 'sabinyl' pathway. As a result, the most common chemotype of this subspecies is a sabinyl type, rich in sesquiterpenes $[8,16]$. In the present work, most of populations belong to sabinyl chemotype, pure (populations no $1,3,13$ ) or mixed (populations no $4,5,9,10,11,14$ ) (tab. 4). In the case of populations no 10 and 14, sabinene was accompanied by a high share of linalool. This compound was also present in considerable amounts in populations no $7,8,12$ (distinguished as mixed acyclic + sesquiterpenes types) and in population no 6 (up to $32.12 \%$ ), classified as pure acyclic chemotype. High percentage of linalool in essential oil is characteristic for O. vulgare subsp. virens, occurring mainly on Iberian Peninsula $[8,11]$. This compound and its derivatives appears only sporadic in O. vulgare subsp. vulgare and extremely rare in populations from Central and Northern Europe $[8,15,16,23]$. However, the presence of linalool-rich common oregano population (up to $15.60 \%$ ) on the area of Poland was reported earlier by Węglarz et al. [26]. Some authors point to the relationship between the essential oil profile and morphological traits of this species, e.g. color of flower's petals [21, 37]. As it was mentioned, the content and composition of essential oil in $O$. vulgare is visibly associated both with latitude and longitude [1, 8, 9]. Lukas et al. [8] observed an increasing west-east gradient in total essential oil yield and carvacrol/thymol amount in $O$. vulgare populations located from the Iberian to Balkan Peninsula. Results obtained in the present work do not indicate any clear relationship between essential oil composition, morphological features and geographical origin of populations. It can be suspected that the area of the research, including three Polish Voivodeships, was too small to observe such a correlation.

In general, practical application of O. vulgare (especially hirtum subspecies) essential oil results from its high antimicrobial activity, caused mainly by carvacrol/thymol domination [38]. Although O. vulgare subsp. vulgare contains small amounts of these active phenolic monoterpenes, this subspecies also indicate such activity, associated in this case with a high content of sabinene $[39,40]$. However, populations rich in linalool and/or sesquirepenes (i.a. $\beta$-caryophyllene) can be interested from the practical point of view, as well. Due to a pleasant aroma of these substances, linalool and/or sesquirepenes-rich chemotypes of $O$. vulgare subsp. vulgare may be used in cosmetic industry.

To sum up, it seems that investigations on the phenomenon of extraordinary variability within $O$. vulgare species and subspecies are still up to 
date. Although many attempts providing to order and understand this issue, there are too many exceptions, especially in the area of chemical diversity, to take over clear rules. Thus, Origanum taxa can create new opportunities promising both from scientific and practice point of view.

\section{CONCLUSIONS}

1. Investigated common oregano populations evaluated in ex situ conditions differed in terms of morphological and developmental traits as well as content and composition of essential oil.

2. Regarding morphological features, number of stems and fresh mass of herb differentiated among examined populations at the highest degree.

3. Given essential oil composition, most of populations were classified as sabinyl chemotype rich in sesquiterpenes.

4. There was no clear correlation between geographical origin of populations and evaluated traits nor between morphological characters and chemical composition of essential oils.

\section{ACKNOWLEDGEMENTS}

The studies were supported by the Polish Ministry of Agriculture and Rural Development, within the Multiannual Programme 'Creating the Scientific Basis of the Biological Progress and Conservation of Plant Genetic Resources as a Source of Innovation to Support Sustainable Agriculture and Food Security of the Country' - task 1.2.

Conflict of interest: Authors declare no conflict of interest.

\section{REFERENCES}

1. Kokkini S. Taxonomy, diversity and distribution of Origanum species. In: Proceedings of the IPGRI International Workshop on Oregano; 1997 May 8-12; Valenzano (Bari), Italy 1997:122-132.

2. Chishti S, Kaloo ZA, Sultan P. Medicinal importance of genus Origanum: A review. J Phar- macognosy Phytother 2013; 5(10):170-177. doi: http://dx.doi.org/10.5897/JPP2013.0285

3. Baricevic D, Bartol T. The biological/pharmacological activity of the Origanum genus. In: Kintzios S ed. Medicinal and Aromatic Plants Industrial Profiles. London 2002:176-213.

4. Alexopoulos A, Plessas S, Kimbaris A, Varvatou M, Mantzourani I, Fournomiti M et al. Mode of antimicrobial action of Origanum vulgare essential oil against clinical pathogens. Curr Res Nutr Food Sci 2017; 5(2):109-115. doi: http://dx.doi. org/ 10.12944/CRNFSJ.5.2.07

5. Leyva-López N, Gutiérrez-Grijalva E P, VazquezOlivo G, Heredia JB. Essential oils of oregano: biological activity beyond their antimicrobial properties. Molecules 2017; 22(6):1-24. doi: http:// dx.doi.org/10.3390/molecules22060989

6. Asdal A, Galambosi B, Bjorn G, Olsson K, Pihlik $\mathrm{U}$, Radušiene J et al. Spice and medicinal plants in the Nordic and Baltic countries. Conservation of genetic resources. In: Report from a project group at the Nordic Gene Bank; Alnarp, Norway. 2006:157.

7. Ietswaart JH. A Taxonomic Revision of the Genus Origanum. Leiden. Leiden University Press, 1980.

8. Lukas B, Schmiderer C, Novak J. Essential oil diversity of European Origanum vulgare L. (Lamiaceae). Phytochem 2015; 119:32-40. doi: http:// dx.doi.org/10.1016/j.phytochem.2015.09.008

9. Skoula M, Harborne JB. The taxonomy and chemistry of Origanum. In: Kintzios S ed. Oregano: the Genera Origanum and Lippia. London 2002:67-108.

10. Azizi A, Hadian J, Gholami M, Friedt W, Honermeier B. Correlations between genetic, morphological and chemical diversities in a germplasm collection of the medicinal plant Origanum vulgare L. Chem Biodiv 2012; 9:2784-2801. doi: http://dx.doi.org/10.1002/cbdv.201200125

11. D’Antuono L, Galletti G, Bocchini P. Variability of essential oil content and composition of Origanum vulgare L. populations from a north Mediterranean area (Liguria region, Northern Italy). Ann Bot 2000; 86:471-478. doi: http://dx.doi. org/10.1006/anbo.2000.1205 
12. Nurzyńska-Wierdak R. Lebiodka pospolita (Origanum vulgare L.) - dziko rosnaca i uprawiana roślina zielarska. Annales UMCS 2012; 22(4):111.

13. Mechergui K, Jaouadi W, Coelho J, Larbi Khouja M. Effect of harvest year on production, chemical composition and antioxidant activities of essential oil of oregano (Origanum vulgare subsp. glandulosum (Desf.) Ietswaart) growing in North Africa. Ind Crop Prod 2016; 90:32-37. doi: http://dx.doi. org/10.1016/j.indcrop.2016.06.0110926-6690

14. De Martino L, De Feo V, Formisano C, Mignola E, Senatore F. Chemical composition and antimicrobial activity of the essential oils from three chemotypes of Origanum vulgare L. ssp. hirtum (Link) Ietswaart growing wild in Campania (Southern Italy) Molecules 2009; 14:2735-2746.

15. Ali Andi S, Nazeri V, Hadian J, Zamani Z. Variability of essential oil composition of Origanum vulgare ssp. vulgare populations from Iran. Med Arom Plant Sci Biotechnol 2011; 5(2):152-155.

16. Lukas B, Schmiderer C, Novak J. Phytochemical diversity of Origanum vulgare L. subsp. vulgare (Lamiaceae) from Austria. Bioch Syst Ecol 2013; 50:106-113. doi: http://dx.doi.org/10.1016/j. bse.2013.03.037

17. Elezi F, Plaku F, Ibraliu A, Stefkov G, Karapandzova M, Kulevanova $S$ et al. Genetic variation of oregano (Origanum vulgare L.) for etheric oil in Albania. Agric Sci 2013; 4(9):449-453. doi: http:// dx.doi.org/10.4236/as.2013.49060

18. Gong HY, Liu WH, Lv GY, Zhou X. Analysis of essential oils of Origanum vulgare from six production areas of China and Pakistan. Bras J Pharm 2014; 24:25-32. doi: http://dx.doi.org/ 0.1590/0102-695X2014241434

19. Bisht D, Chanotiya C, Rana M, Semwa M. Variability in essential oil and bioactive chiral monoterpenoid compositions of Indian oregano (Origanum vulgare L.) populations from northwestern Himalaya and their chemotaxonomy. Ind Crop Prod 2009; 30:422-426. http://dx.doi.org/ 10.1016/j.indcrop.2009.07.014

20. Matuszkiewicz W. Przewodnik do oznaczania zbiorowisk roślinnych Polski. Warszawa 2011.
21. Mockute D, Bernotiene G, Judžentiene A. The essential oil of Origanum vulgare L. ssp. vulgare growing wild in Vilnius district (Lithuania). Phytochem 2001; 57(1):65-69. doi: http://dx.doi.org/ 10.1016/S0031-9422(00)00474-X

22. Mockute D, Bernotiene G, Judžentienè A. The $\beta$-ocimene chemotype of essential oils of the inflorescences and the leaves with stems from Origanum vulgare ssp. vulgare growing wild in Lithuania. Bioch Syst Ecol 2003; 31:269-278. doi: http:// dx.doi.org/10.1016/S0305-1978(02)00151-5

23. Mockutè D, Bernotienè G, Judžentienè A. Chemical composition of essential oils of Origanum vulgare L. growing in Lithuania. Biol 2004; (4):44-49.

24. Vazirian M, Mohammadi M, Farzaei MH, Amin G, Amanzadeh Y. Chemical composition and antioxidant activity of Origanum vulgare subsp. vulgare essential oil from Iran. Res J Pharm 2015; 2(1):41-46.

25. Kula J, Majda T, Stoyanova A, Georgiev E. Chemical composition of Origanum vulgare L. essential oil from Bulgaria. J Essent Oil Bear Pl 2007; 10:215-220.

26. Węglarz Z, Osińska E, Geszprych A, Przybył J. Intraspecific variability of wild marjoram (Origanum vulgare L.) naturally occurring in Poland. Braz J Med Pl 2006; 8:23-26.

27. Kosakowska O, Bączek K, Geszprych A, Węglarz Z. Ocena składu chemicznego olejku eterycznego dziko rosnących populacji lebiodki pospolitej (Origanum vulgare L.). Pol J Agr 2013; 15(15):6771.

28. Chalchat JC, Pasquier B. Morphological and chemical studies of Origanum clones: Origanum vulgare L. ssp. vulgare. J Essent Oil Res 1998; 11:143-144.

29. Radusiene J, Ivanauskas L, Janulis V, Jakstas V. Composition and variability of phenolic compounds in Origanum vulgare from Lithuania. Biol 2008: 54(1):45-49.

30. Senderski ME. Zioła. Praktyczny poradnik o ziołach i ziołolecznictwie. Wyd. E.P. Liber, 2014.

31. Osińska E. Ocena zmienności morfologicznorozwojowej i chemicznej kilkunastu populacji 
lebiodki pospolitej (Origanum vulgare L.). Rocz AR Pozn 2000; (31)323:391-5.

32. Bączek K, Kosakowska O, Przybył J, Kuźma P, Ejdys M, Obiedziński M, Węglarz Z. Intraspecific variability of yarrow (Achillea millefolium L. s.l) in respect of developmental and chemical traits. Herba Pol 2015; 61(3):37-52. doi: http://dx.doi. org/10.1515/hepo-2015-0021

33. Žukauska I, Sivicka I. Draft Descriptor List Origanum vulgare L., European Cooperative Programme for Plant Genetic Resources Rome, Italy 2011.

34. European Pharmacopoeia 8th ed. European Directorate for the Quality of Medicines and Health Care (EDQM), Council of Europe, Strasbourg 2008.

35. Sivicka I, Žukauska I, Adamovičs A. Aspects of morphological diversity of oregano in Latvia. Mod Phytomor 2013; 4:61-64.

36. Sivicka I, Žukauska I, Balode A, Adamovičs A. Fresh and air-dry biomass of oregano (Origanum vulgare L.) accessions. In: 25th Congress Nordic View to Sustainable Rural Development; 2015 June 16-18, 46-51.
37. Bocchini P, Russo M, Galletti GC. Pyrolysis gaschromatography/mass spectrometry used as a microanalytical technique for the characterization of Origanum heracleoticum from Calabria, Southern Italy. Rap Com Mass Spect 1998;12(20): 1555-1563.

38. Nostro A, Roccaro AS, Bisignano G, Marino A, Cannatelli M, Pizzimenti FC et al. Effects of oregano, carvacrol and thymol on Staphylococcus aureus and Staphylococcus epidermidis biofilms. J Med Microbiol 2007; 56(4):519-523. doi: http:// dx.doi.org/10.1099/jmm.0.46804-0

39. Matias FFE, Alves EF, Silva KNM, Carvalho VRA, Figueredo FG, Ferreira JVA et al. Seasonal variation, chemical composition and biological activity of the essential oil of Cordia verbenacea DC (Boraginaceae) and the sabinene. Ind Crop Prod 2016; 87:45-53. doi: http://dx.doi.org/10.1016/j. indcrop.2016.04.028

40. Cao Y, Zhang H, Liu H, Liu W, Zhang R, Xian $\mathrm{M}$ et al. Biosynthesis and production of sabinenr: current state and perspectives. Ap Mirob Biotech 2017. doi: http://dx.doi.org/10.1007/s00253-0178695-5

\title{
Zróżnicowanie morfologiczne i chemiczne lebiodki pospolitej (Origanum vulgare L. subsp. vulgare) występującej na terenie wschodniej Polski
}

\author{
OLGA KOSAKOWSKA*, WERONIKA CZUPA
}

\author{
Laboratorium Nowych Technologii Wytwarzania Produktów Zielarskich i Oceny ich Jakości \\ Katedra Roślin Warzywnych i Leczniczych \\ Szkoła Główna Gospodarstwa Wiejskiego w Warszawie \\ ul. Nowoursynowska 166 \\ 02-787 Warszawa
}

*autor, do którego należy kierować korespondencję: tel. +48 22 5932247, faks +48 225932232 , e-mail: olga_kosakowska@sggw.pl 


\section{Streszczenie}

Wstęp: Lebiodka pospolita jest ważną rośliną leczniczą i aromatyczną, charakteryzującą się wysoką zmiennością morfologiczną oraz chemiczną.

Cel: Celem pracy było określenie różnic pomiędzy 14 populacjami lebiodki pospolitej rosnącymi w warunkach ex situ, pod względem cech morfologiczno-rozwojowych, a także co do zawartości i składu chemicznego olejku eterycznego w zielu.

Metody: Obserwacje przeprowadzono w drugim roku wegetacji roślin. Ocenione zostały cechy morfologiczno-rozwojowe, oznaczono zawartość olejku eterycznego (wg Farmakopei Europejskiej 8) oraz jego skład chemiczny (metodą chromatografii gazowej).

Wyniki: Populacje różniły się pod względem analizowanych cech. Wysokość roślin wahała się od 52,13 do 88,66 cm, liczba pędów na roślinę od 45,6 do 123,3, liczba międzywęźli na pędzie od 4,6 do 9,2. Świeża masa ziela kształtowała się na poziomie 249,0-896,6 g na roślinę. Zawartość olejku wynosiła od 0,35 do 0,87\%. Związkami dominującymi w olejku były: sabinen, 1,8-cineol, linalol, $p$-cymen, $\beta$-kariofilen i tlenek kariofilenu.

Wnioski: Cechami, które najbardziej różnicowały badane populacje była liczba pędów oraz świeża masa ziela. Większość populacji zaklasyfikowano jako chemotyp sabinylowy, bogaty w seskwiterpeny.

Słowa kluczowe: lebiodka pospolita, populacje, olejek eteryczny, chemotypy, zróżnicowanie 